\title{
Agribusiness as a Factor of Regional Development in Eastern Poland
}

\author{
Barbara GOŁĘBIEWSKA, Joanna STEFAŃCZYK \\ Warsaw University of Life Sciences, Warsaw, Poland \\ barbara golebiewska@sggw, pl, \\ joanna_stefanczyk@sggw.pl
}

\begin{abstract}
Changes in the development of individual regions in Poland are a result of many factors. Among them significant is the initiative of the inhabitants to undertake business, its development or expansion. The aim of the study was to characterize and evaluate a selected branch of agribusiness in the eastern region of Poland. In order to achieve this aim, the results of our own surveys were carried out among 115 entrepreneurs associated in various types of associations operating in the rural areas of the eastern region. The motivations to start the agritourist activity of the respondents, the conditions of conducting such activity and the support or lack thereof in the entrepreneur's environment were assessed. According to the analysis, the desire to start and continue agritourism activity is largely driven by a favorable environment both in the social and natural sphere. Agritourism is perceived as a positive factor in the advertising and enrichment of a given region, so it should be supported not only by the neighboring agritourism owner but also by the regional authorities. It should be assumed that as a result of relatively more financial and educational assistance for farmers, there will be an increased interest in starting development initiatives for agribusiness activities among the inhabitants of the region.
\end{abstract}

Keywords: Regional Development, Agribusiness, Region.

\section{Introduction}

Membership in the European Union and the associated with this inflow of funds to agriculture enabled farms to undertake their own development activities, and the regional authorities were given the opportunity to change the face of Polish villages and towns, for example through technical and social development [13]. When traveling in Poland, it can be seen that many rural areas have become more attractive in terms of living or doing business, but to reduce the disparity of living conditions between rural and urban areas, it is necessary to create new jobs and earn extra income outside agriculture, especially if the farm area is small with no prospects for increasing the area of agricultural land. According to Woś [20], agritourism can be an additional and alternative form of activity for them, particularly important for small farms with unfavorable agrarian structure and low financial condition. Especially because of the statistics present the use of domestic tourism are beneficial to the accommodation. A similar situation exists in other EU countries. Žlábková [22] 
indicates that in the Czech Republic there is a great potential for the development of tourism in rural areas as a non-productive function of agriculture.

According to the data of the Central Statistical Office in Poland in the first three months of 2017, compared to the first quarter of 2016, the number of tourists using the accommodation base was increased by $8.5 \%$ and the number of overnight stays by $6.0 \%$. At the same time, the number of foreign tourists increased by $4.0 \%$ and the number of rooms rented by them was $2.3 \%$ [21].

\section{Regional development - literature overview}

The allocation of development within the boundaries of the region obliges to indicate a specific area. In terms of etymology (Latin regio) it would be an area associated with a province or a district, but today the term is identified with a part of the country (state), characterized by characteristic features [6]. On this basis one of the regions in Poland was classified as PL3 by NUTS division, the Eastern Region, consisting of Lubelskie, Podkarpackie, Świętokrzyskie and Podlaskie voivodships. Sadowski in his publication pointed out that the Polish eastern borderlands have for years been marked with a stigma of weakness, peripheral or backwardness, and the various forms of pressure that have been taking place for many years have caused both individual attitudes and public life and even scientific publications., there is a generalized belief that there is indeed such a objectivized phenomenon as Eastern Poland, distinguished by many distinctive features in relation to Western Poland and that these features are mostly negative [17]. For this reason, the Eastern Region was selected for research in order to identify residents' interest in undertaking development initiatives.

Głuszczuk [6] states that regional development in economic terms is determined by economic growth and is reflected in the transformation of factors and economic resources (internal and external to the region) into increased production of goods and services. In the social sense, it involves changes in interpersonal relations and social structure, which translates into a modification of the way and a higher quality of life of the inhabitants. Technical and technological components include all progressive changes in the degree of modernity and quality of manufactured goods and services, their assortment as well as the material structure of the manufacturing apparatus (fuller, more rational use of resources and resources of the region). According to the Szlachta, regional development is a systematic improvement of the competitiveness of economic entities and the standard of living of the inhabitants as well as the economic potential of the regions contributing to the socio-economic development of the country [18]. On the other hand, socio-economic development, according to Chojnicki and Czyż, is a set of targeted changes that occur in different spheres of social, economic, political, institutional, cultural, biological, ecological and protection of environment [4]. Balinska adds that regional and local development is strongly connected with the competitiveness, entrepreneurship and innovation of both the territorial units themselves and the entities located therein [2]. In regional literature, regional development is perceived as a process of improving conditions in poorlydeveloped or transitional regions [3]. It should be highlighted that according to some 
authors, local development is the same as regional development, and the only difference is the size of the territorial unit involved in the development study [12].

One of the possible forms of development of the region is starting agritourism by its inhabitants. Kachniewska investigated that the development of tourism allows to stop migration from the village and positively influences the condition and quality of the manpower [10]. Farm tourism is a tourist activity conducted on farms, and as Firlej adds, it is one of the most important spheres of tourist activity in rural areas, which expanded broadly in Poland in the early 1990s, using farmland as a base for accommodation [5]. Wiatrak defines agritourism as organizing the tourists' stay by the agricultural family in their own farm. The agritourism offer is a stay in the farm (accommodation), which can be combined (depending on the conditions) with full board or the possibility of buying fresh produce from the farm for self-catering [19]. Roman adds that agritourism is a viable alternative to creating new jobs, sources of income and raising overall levels and lifestyles [16]. Gołębiewska notes that the importance of rural tourism has been growing in recent years. This is due to the fact that in rural Europe, rural tourism has until recently been responsible for $10 \%$ of the demand for holiday services, and on average 3 to $5 \%$ of farms provide such services. The increase in tourist employment in rural areas of the EU is higher than in urban centers and mainly concerns recreational services [8]. The development of agritourism in Poland in recent years has become significant from the point of view of economic practice as well as the development of scientific tools for its analysis [7]. According to Marcinkiewicz, almost every second person, even once in his life, became a tourist and changed his place of residence to rest, get closer to his country or experience new places. In addition, the author points out that tourism often contributes to urbanization of the countryside, causing cultural and economic changes and stimulating the development of the construction industry. Rural areas themselves are subject to a complex process of change [14], thus contributing to the development of rural areas. Balińska and Zawadka show that agritourism in Poland has been developing continuously since the beginning of the 1990s and as an economic, social, cultural and spatial phenomenon, it integrates in its essence the factors stimulating local development [1]. The research conducted by Karbowiak shows that the owners surveyed by the agritourist business on the basis of the suggestion of the guests introduced changes in their services, which they claimed were noticed and contributed to the consolidation of relations with customers, because they showed a willingness to develop their services [11]. In recent years, agritourism has become one of the most popular forms of recreation - says Jęczmyk and Bogusz [9]. Balińska adds that it is precisely thanks to the development of tourism that promotion of products manufactured in the reception area, the region and even the country is also taking place. This results in improved image and better positioning of both the area itself and the individual products in the minds of potential consumers. This phenomenon is not only a marketing dimension but also an economic one, as it leads to an intensification of demand for these products. This may include food (such as wine, cheese, honey, and spices), ornaments and decorations, as well as durable goods (including high technology) [2]. 
In 2017, the "Regional Review of Poland 2016 Part II" was published in Warsaw, which presented the developmental situation of the Polish Nuts 2 distribution units. It contained data on the four voivodships constituting the discussed Eastern Region. According to the report of the Ministry of Development characteristic for the Lubelskie voivodeship is suburbanization. As a result, the number of inhabitants of rural areas and smaller towns located near the largest urban centers has steadily increased. As a result, the value of the urbanization index decreases. City dwellers in 2015 accounted for $46.18 \%$ of the total population of the voivodship. The number of inhabitants of rural areas is growing. The employment rate in the voivodship is rising, while the level of registered unemployment is slightly decreasing [15]. The excerpt of the cited report can be interpreted as an interest in living in rural areas, which is a positive condition for starting an agribusiness activity in this area.

Podlaskie voivodeship is perceived by the prism of naturalness - among the 16 voivodships in Poland, the region is characterized by the largest number of protected areas in the form of national parks and the NATURA 2000 network. This situation has a positive impact on the quality of life in the region and can be used to build competitive advantage in the green Industry [15]. In this case of the Eastern Region, a ministerial report indicates that the area has competitive natural values to develop its agribusiness services - including agri-tourism.

Podkarpackie is one of the voivodships in Poland, where the level of European funds per capita was the highest. The province occupies the 3rd position in the country [15]. The presented activity on the grounds of obtaining European funds may be indicative of the willingness of the inhabitants and entrepreneurs of the voivodeship.

In the Świętokrzyskie region, 54 cultural facilities were built / modernized, 31 health infrastructure projects completed, 66 projects completed in the field of tourism were completed, and 213.98 new jobs were created in the field of tourism [15]. The data show a positive attitude towards tourism, including agritourism.

On the basis of fragments of the ministerial report on the development of the NUTS2 regions in Poland, it was noted that four voivodships constituting the Eastern Region, although commonly called "delayed" in relation to other regions of Poland, show great interest in development and have appropriate conditions, Our own research indicates that the respondents' high awareness of agri-tourism and other agribusiness activities has been confirmed.

\section{Methodology}

The purpose of this study was to describe and evaluate the agritourism activity among the inhabitants of the Eastern Region in Poland. The study was conducted in the first quarter of 2017. The choice of territorial scope of research has been decided by the fact that this region is widely considered to be the least developed in Poland. The research questionnaire was used in a traditional way to distribute 40 types of associations, clubs and organizations of people living in rural areas of the Eastern Region. Each letter contained from 5 to 10 questionnaires, depending on the size of 
the organization. A total of 115 duly completed questionnaires received statistical analysis after a 2-month follow-up period. The survey questionnaire was addressed both to respondents with and without agritourism. Non-agritourism respondents were asked to respond to questions assessing this activity from the respondents' point of view as potential recipients of such services. Materials derived from analyzes prepared by the Regional Territorial Observatories issued by the Ministry of Development were also used. The collected materials were prepared in graphical form, tabular, descriptive statistics were also used.

\section{Results}

\subsection{Survey of respondents with agritourism activities}

Farmers responded to the question about the length of their service activities (see Fig. 1). Among the respondents were people engaged in running agritourism very briefly, but mainly they were agritourism business owners of several or many years.

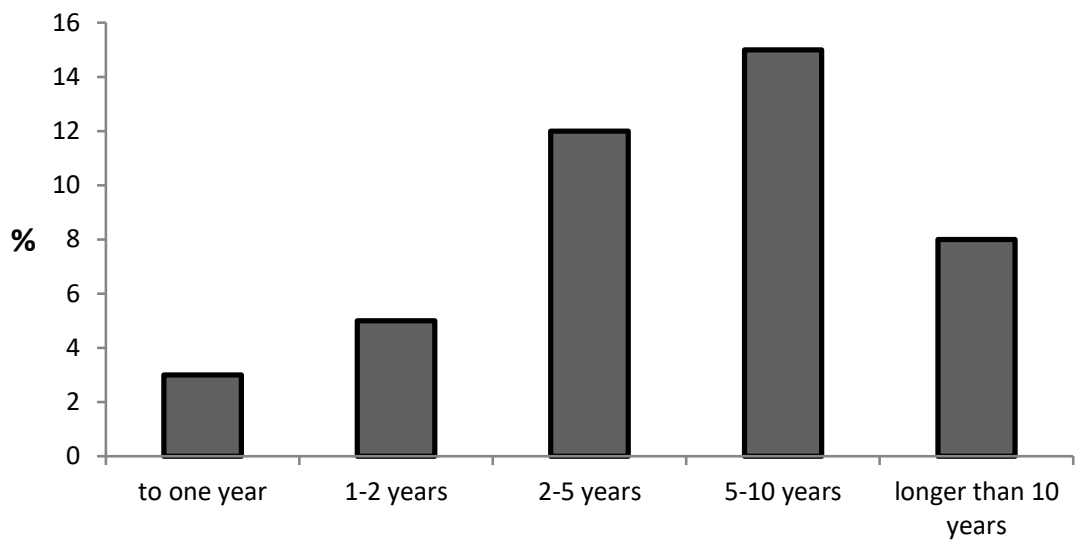

Fig. 1. The length of agritourism activity [in years]

New farms operating less than a year were only $3 \%$. Almost $15 \%$ of owners have been engaged in this activity for 5 to 10 years. This indicates that most of the respondents had experience in running an agritourism business, which may indicate a greater perception in this regard. The increase in the number of agrotourism farms was not large. This indicates a slow increase in the activity of rural residents (including the development of agritourism) and also indicates the slow development of rural areas in Poland.

Farmers were asked to select the three most important characteristics describing a good agritourism owner (see Fig. 2). Besides to courtesy, the necessary qualities for running the business are independence and entrepreneurship. 


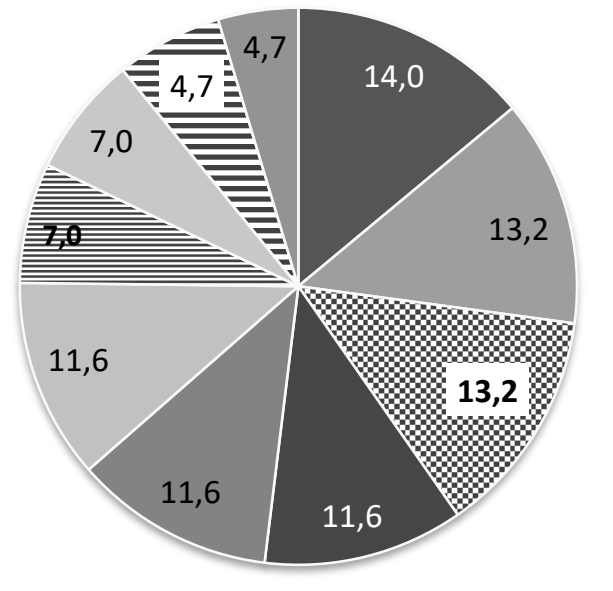

$$
\begin{aligned}
& \text { - courtesy } \\
& \square \text { independence } \\
& z \text { entrepreneurship } \\
& \square \text { patience } \\
& \square \text { flair } \\
& \square \text { responsibility } \\
& \equiv \text { openness } \\
& \square \text { honesty } \\
& =\text { ingenuity } \\
& \square \text { creativity }
\end{aligned}
$$

Fig. 2. Characteristics that a person associated with agritourism should have [in \%]

The correlation between the number of years of agritourism activity and customer service quality, service standards improvement, service provider surroundings, preparation of offers and offering discounts was calculated. The coefficients of correlation determined are significant at $\mathrm{p}<0.05$, with $\mathrm{N}=43$. For the above variables, the following results were obtained: 0.198486, 0.000785, 0.073787, 0.000517 , and 0.083471 . It was noted that the only significant correlation occurred for the variable - high customer service at 0.119486, which was a low positive correlation, and meant that as the number of years of agritourism increased, customer service quality increased. The other variables did not show any association with the examined trait.

Respondents who were asked to choose the three best qualities were considered to be resourceful, entrepreneurial and supportive family and friends (see Fig. 3). 


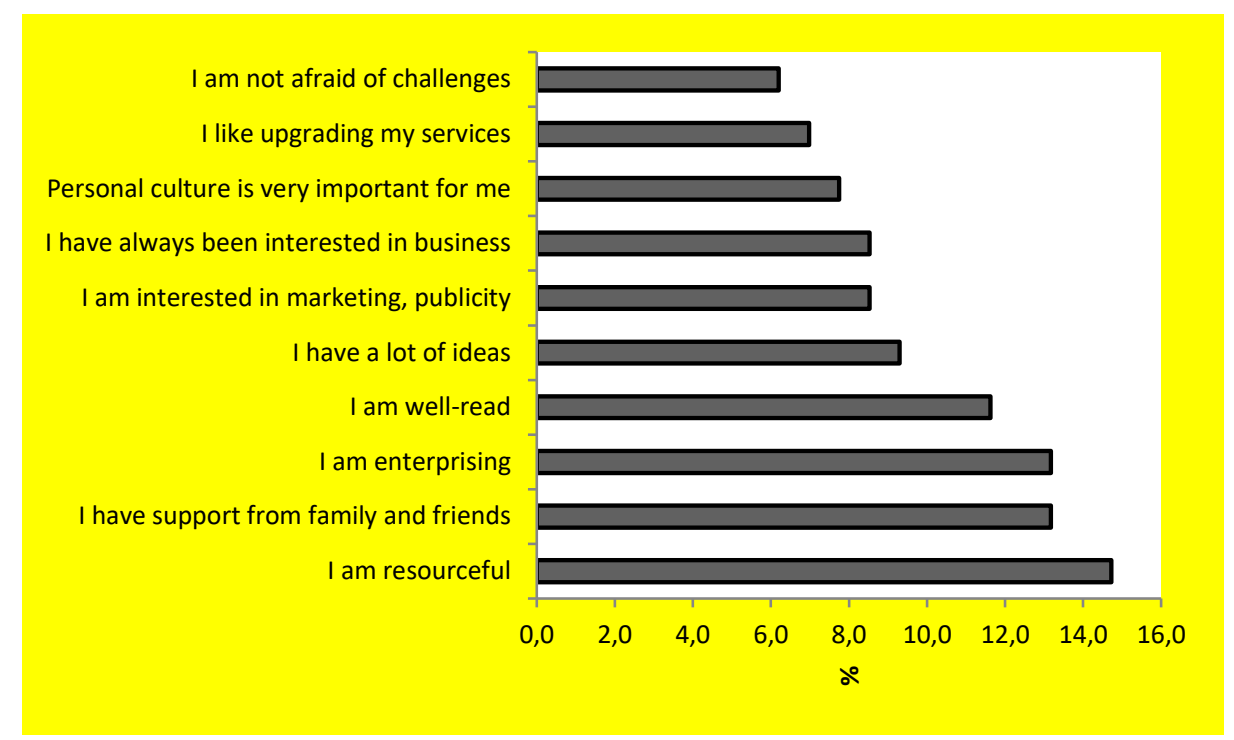

Fig. 3. Characteristics of the owner of the agritourism [in \%]

Less than $60 \%$ of survey respondents conducted their services seasonally, while slightly over $40 \%$ had a yearly offer (see Fig. 4).

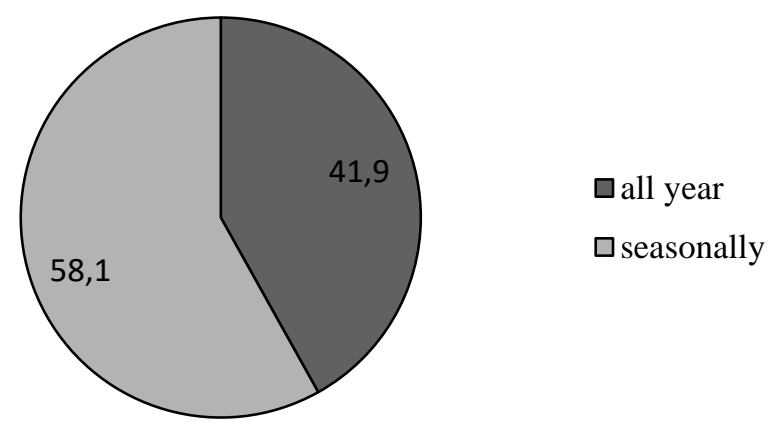

Fig. 4. Preparation of the agritourism offer [in \%]

Respondents also answered the question of who or what prompted them to start the agritourism business. Most responded that they had motivation from family. Some of them may have been modeled on relatives who have already conducted such activities, and some have observed such activities in their area and it has motivated them to make an effort. A small proportion of the respondents were encouraged to participate in meetings or trainings organized by the municipality / district (see Fig. 
5). At the same time, almost $90 \%$ of them showed willingness to participate in a meeting organized to promote the start of agritourism and other agribusiness.

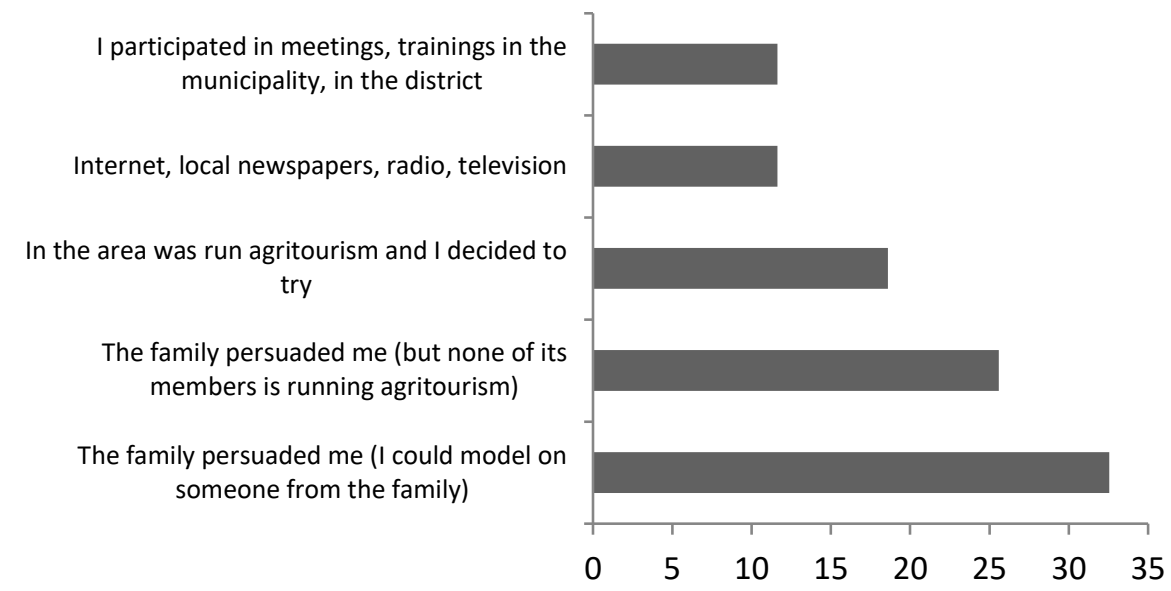

Fig. 5. The source of idea to start agritourism business [in \%]

\subsection{Rating among non-agritourist activities}

The non-agritourism respondents, who were also asked for feedback on the suitability of agritourism for regional development. They were asked about the aspects that they consider necessary for conducting such activities. Among the answers given were predominantly those that indicated the predisposition of young people and the need for funds to start such activities (more than $50 \%$ of respondents) (see Fig. 6)

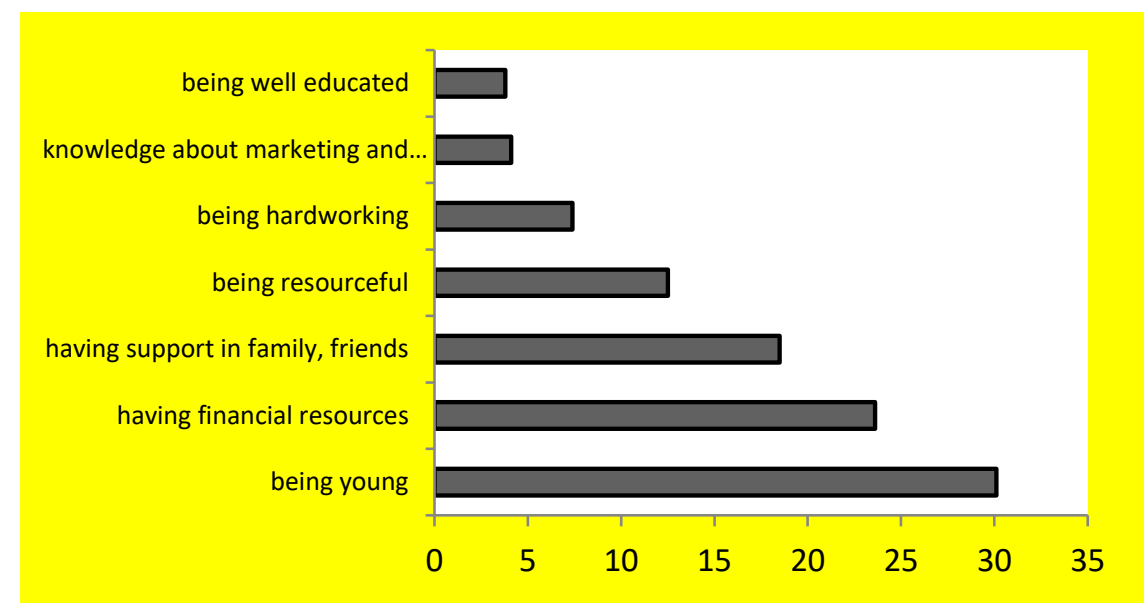

Fig. 6. The necessary aspects for running a business [in \%] 
Among respondents without agritourism, $16.7 \%$ of respondents said that they were thinking about it, while $83.3 \%$ were not willing. In turn, only $13.9 \%$ of respondents perceived the provision of agritourism services as difficult in terms of service from the documentation of activities (launching activities). For over $86 \%$ this would not be a problem. Respondents were asked to indicate the intensity of agro-tourism occurring in their area of residence, and more than $40 \%$ indicated that they know of one (at least one) farm and $50 \%$ have information about many of these. Less than $10 \%$ responded that there are no agritourism farms in their area. Previously, the people who confirmed that they were thinking about running agritourism were also in the group of respondents who declared knowledge of at least one activity in the area of residence. The relationship between these variables, the willingness to work and the knowledge of farms in the area, was 0.56 , that is, according to the Guillford classification it is in the range of $0.5<|\mathrm{r}| \leq 0,70,5<|\mathrm{r}| \leq 0,7$, so it is a high positive correlation.

The non-agritourist East Region residents were asked to indicate what agritourism business is for the municipality (see Fig. 7).

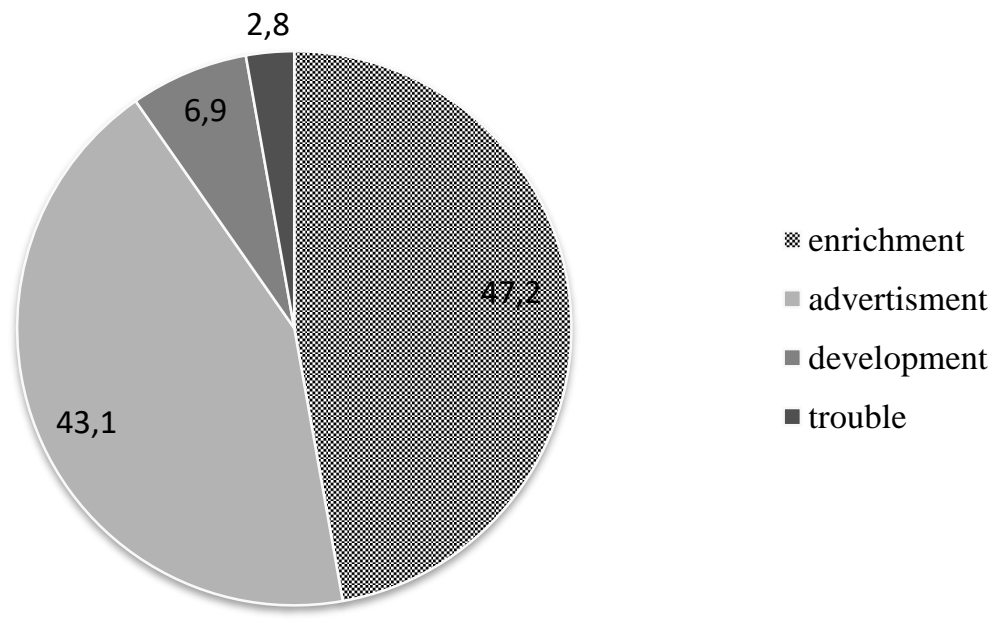

Fig. 7. The importance of agritourism for the commune [in \%]

More than $90 \%$ of respondents said that the agritourism in the area of the commune is its advertising and thanks to it the community is enriched. Less than $7 \%$ chose a broader response and indicated that this could contribute to the development of the municipality, with the responses being interrelated. Commercialization of the community will be connected with greater opportunities for its development, and direct enrichment also indicates development. Less than $3 \%$ gave a negative answer and found it to be a problem for the residents, mainly due to disturbances that may be related to strangers in the municipality.

The respondents, who were asked about the financial aspect, found that agritourism can help generate high incomes and contribute to development, although it also 
requires continuous investment (43\%). However, evaluating it for their own benefit, $57 \%$ saw no chance of a serious paycheck. This indicates that respondents in the assessment of their own activities were more pessimistic than the general problem $(47.2 \%)$. At the same time, more than half of the respondents stated that they had conditions for running agrotourism services, and $100 \%$ of respondents admitted that appropriate natural conditions (high natural areas) were required to conduct such activities.

\section{Conclusion}

According to analyzes of respondents' answers and the ministerial report, the willingness to start agritourism or other agribusiness activities, and the possibility of its continuation, is largely dictated by a favorable environment both in the social and natural spheres. Agritourism is perceived as a positive factor in the advertising and enrichment of a given region, so it should be supported not only by the neighboring agro-tourism owner but also by the regional authorities. It should be assumed that as a result of relatively more financial and educational assistance for farmers, there will be an increased interest in initiating development initiatives for agribusiness activities among the inhabitants of the region. Residents of the Eastern Region have shown willingness to meet, start training, or improve their business, as far as their location is concerned. Agritourism is a development activity for the region and its inhabitants. It creates jobs, lowers unemployment, promotes the region, and with the right level of service and consumer interest can be the basis for attracting investment.

\section{References}

1. Balińska, A., Zawadka, J.: The importance of rural tourism in rural development. Znaczenie agroturystyki w rozwoju obszarów wiejskich. WULS-SGGW Scientific Papers in Warsaw. Economics and Organization of Food Economy no 102, 127-143 (2013).

2. Balińska, A.: The importance of tourism in the development of rural communities on the example of peripheral areas of the eastern border of Poland. Znaczenie turystyki w rozwoju gmin wiejskich na przykładzie obszarów peryferyjnych wschodniego pogranicza Polski. SGGW Publishing House, Warsaw (2016).

3. Bingham, R.D., Mier, R.: Theories of local economic development: perspectives from across the disciplines. SAGE Publications, Newbury Park (1993).

4. Chojnicki, Z., Czyż, T.: Regional aspects of the knowledge economy in Poland. Aspekty regionalne gospodarki opartej na wiedzy w Polsce. Bogucki Scientific Publishing House, Poznań (2006).

5. Firlej, K.: Condition and possibilities of agritourism development in Poland. Stan i możliwości rozwoju agroturystyki w Polsce. Publishing House of the Institute of Public Affairs of the Jagiellonian University, Cracow (2002).

6. Głuszczuk, D.: The essence of regional development and its determinants. Istota rozwoju regionalnego i jego determinanty. Ekonomia Economics 5(17), 68-80 (2011).

7. Gołębiewska, B.: Economic conditions of development of polish agritourism. Hradec Economic Days Vol. 5(4), 166-173 (2015). 
8. Gołębiewska, B.: Rural tourism as a form of non-farming business activity in the polish countryside. Economic Science for Rural Development 16, 49-55 (2008).

9. Jęczmyk, A., Bogusz, M.: Educational farms as an example of the polish agritourism farms specialization. Hradec Economic Days 7(1), 356-362 (2017).

10. Kachniewska, M.: Tourist function as a determinant of quality of life in the countryside. Funkcja turystyczna jako determinanta jakości życia na wsi. Folia Pomeranae Universitatis Technologiae Stetinenis, Oeconomica 288 (64), 53-72 (2011).

11. Karbowiak K.: Building relationships with clients in agritourism - a challenge or a necessity? Budowanie relacji z klientem w agroturystyce - wyzwanie czy konieczność? Association of Agronomists and Agribusiness Researchers 16 (6), 208-212 (2014).

12. Kosiedowski, W.: Local government in the process of regional and local development. Samorząd terytorialny w procesie rozwoju regionalnego i lokalnego. Organizator's house, Toruń (2005).

13. Marciniak, M.: Entrepreneurship development of Polish rural areas. Rozwój przedsiębiorczości szansą polskich obszarów wiejskich. Civic Institute, Warsaw (2011).

14. Marcinkiewicz, C.: The development and condition of Polish agrotourism. Rozwój i stan polskiej agroturystyki. Scientific Papers of Humanitas School. Zarządzanie nr 1, 21-35 (2013).

15. Ministry of Development: Regional Review of Poland 2016 part 2. Analyzes prepared by Regional Territorial Observatories. Ministerstwo Rozwoju: Przegląd Regionalny Polski 2016 część 2. Analizy przygotowane przez Regionalne Obserwatoria Terytorialne. https://www.mr.gov.pl/media/44828/Przeglad_Regionalny_2016-cz2.pdf, last accessed 2017/10/17.

16. Roman, M.: Innovation of rural tourism on the example of Canton Ticino in Switzerland. Innowacyjność turystyki wiejskiej na przykładzie Kantonu Ticino w Szwajcarii. Association of Agronomists and Agribusiness Researchers, 18 (1), 232-240 (2016).

17. Sadowski, A.: East voivodship of the Republic of Poland - conditions for constructing border capital. Wschodnie województwa Rzeczypospolitej - uwarunkowania konstruowania kapitału pogranicza. Social contects 1(2), 8-17 (2013).

18. Szlachta, J.: Main problem of regional development policy in Poland at the turn of the 20th century. Główne problem polityki rozwoju regionalnego Polski na przełomie XX I XXI wieku, [in:] Strategic challenge for Poland's regional development policy. Friedrich Ebert Stiftung Publishing House, Warsaw (1996).

19. Wiatrak, A.: The impact of agritourism on the development of rural areas. Wplyw agroturystyki na zagospodarowanie obszarów wiejskich. Zagadnienia Ekonomiki Rolnej, no 1, 34-46 (1996).

20. Woś, A.: Agrobusiness. Key Text Publishing House, Warsaw (1996).

21. The use of tourist accommodation facilities in the first quarter of 2017. Central Statistical Office, Warsaw 2017. https://stat.gov.pl/obszary-tematyczne/kultura-turystykasport/turystyka/wykorzystanie-turystycznych-obiektow-noclegowych-w-i-kwartale-2017roku,6,10.html, last accessed 2017/10/15.

22. Žlábková, J.: Support for Rural Tourism. Hradec Economic Days 7(1), 986-991 (2017). 